\title{
Short communication \\ HEMATOLOGICAL VALUES IN JUVIENILE PERIODONTITIS PATIENTS IN IBADAN, NIGERIA
}

\author{
DOSUMU E.B ${ }^{1^{*}}$, AROWOJOLU M. $0^{2}$., AKANDE O. $0^{3}$. AND AKINGBOLA T. $\mathrm{S}^{4}$. \\ ${ }_{1,2}$ Department of Preventive Dentistry, College of Medicine, University of Ibadan, \\ ${ }^{3}$ Departments of Physiology/Oral Pathology College of Medicine, University of Ibadan. \\ ${ }^{4}$ Department of Haematology, College of Medicine, University of Ibadan.
}

\begin{abstract}
In this study, clinical and hematological examinations of forty adolescent patients in the group (15-22) years with established clinical features of chronic periodontitis but without any diagnosable medical disease were done. The patients were divided into two Groups (A \&B). Group A were diagnosed as having juvenile periodontitis $(J P)$ while group $B$ had the plaque-induced chronic periodontitis i.e. non- JP and were used as control. We then compared the following hematological features between these two groups and the expected normal values here in the tropics; White Blood Cell (IVBC)-total and differential, Packed Cell Volume (PCV) and the blood film appearance. According to the general blood examination of both groups, almost all the numerical values were within the normal range as compared to the documental normal value in Nigeria. It was therefore concluded that low lymphocyte responsiveness, lymphocyte dysfunction and a deficiency of neutrophil chemotaxis as earlier reported may be involved in the pathogenesis of JP rather than the numerical value of these cells. The relationship of periodontal disease to other neutrophil functions such as phargocytosis and bactericidal activity requires further investigation.
\end{abstract}

Key Words: Hematological values, juvenile periodontitis

${ }^{*}$ Author for correspondence

\section{INTRODUCTION}

Periodontitis is an infectious disease caused by periodontopatic bacteria. The initiation and progression of periodontitis do not always occur in the same manner, because the host defensive mechanism varies among patients and race (Page et al 1985; Genco et al 1986, Genco, 1992); hence this study was designed to evaluate the numerical value of the defense cells in juvenile and non- juvenile periodontitis patients compare with the expected normal values in Nigeria.

\section{MATERIALS AND METHODS}

The study was carried out at the periodontology unit of the Dental School, and Haematology Department, College of Medicine, University of Ibadan, Ibadan. Ethical clearance was obtained from University College Hospital/College of Medicine Ethical Committee. The data were collected at the first visit, that is, before any form of periodontal therapy was begun. Forty patients of the same age range (15-22) years were selected for participation in this study and they were divided into two equal groups. The first group of 20 patients was diagnosed as having Juvenile Periodontitis while the remaining 20 patients had chronic periodontitis sequel to heavy accumulation of plaque and calculus. The second group was used as the control group.

Clinical Examination: Clinical examination was performed on the remaining teeth excluding the third molar and the following criteria were used to describe the conditions (1) the number of teeth missing, that is not sequel to decay (2) probing depth, which was expressed as the mean value of distances from the gingival margin to the base of the gingival crevice measured as four points around each tooth, the mean found and expressed as the value for that tooth.(3) Number of teeth in which the alveolar bone showed resorption of more than half of the root length, which was measured from cementoenamel junction to root apex at an arbitrary point on a radiography by the method described by Schei et al (1959).

We diagnosed the first group with Juvenile Periodontitis due to the age of onset and their clinical findings according to the criteria of Page and Schroder (1982). The graduations of the peripheral whole blood cell, Packed Cell Volume (PCV) and the 
white blood cell (WBC) were examined for both groups.

Laboratory Tests: Approximately $3.0 \mathrm{ml}$ peripheral blood was drawn from each of the participating patients in both groups for hematological WBC (total and differential) and the film appearance. The parameters were determined in hematology unit laboratory of the University College using standard methods.

\section{RESULTS}

Clinical Examination: The clinical findings at the first visit are as shown in Table 1. All the patients showed severe bone resorption with relatively deep mean pockets probing depth and a corresponding mean degree of mobility. The oral hygiene status of the chronic periodontitis patients was poor considering the high value of the mean OM-S index as compared to the JP patients which was fair.

General Blood Examination: The results are shown in Tables 1 and 2. According to their general blood counts all of the values were within normal limits when compared with the accepted normal in the tropics

\section{DISCUSSION}

Early-Onset periodontitis (EOP) may serve as models in which certain pathogenic features are amplified, thus permitting insights into basic mechanisms underlying all forms of periodontitis. (Fenesy, 1998). Epidemiological evidence indicates the existence of high risk groups and suggests that a variety of disease markets (risk factors) may predispose individuals to periodontitis Johnson et al (1988) Some forms of increased disease susceptibility or intrinsic defects may be involved in patients with EOP; for example, neutrophil dysfunction Van Dyke et al (1985), abnormal lymphocyte subsets Kinane et al 1989), and aberrant cytokine production Page et al (1985). Furthermore, a high prevalence of EOP patients in certain families and linkage with specific human leukocyte antigen (HLA) phenotypes have suggested that genetic factors may be involved in some cases and "Common risk factors" have been pointed out in these families. However, studies reported to date have not shown much consistency in the association of HIL.A phenotype with periodontal disease. Nishimura et al (1990) reported that the association between HLA antigens and periodontal disease differs from race to race.

Table 1: Clinical findings at first clinic visit

\begin{tabular}{lll}
\hline Oral examination & JP Patients & $\begin{array}{l}\text { Non JP } \\
\text { patients }\end{array}$ \\
\hline $\begin{array}{l}\text { Mean Probing } \\
\text { Depth }\end{array}$ & $5.70 \pm 1.05$ & $5.38 \pm 0$ \\
\hline Bone Loss (\%) & $46.18 \pm 1.02$ & $44.03 \pm 1.01$ \\
\hline $\begin{array}{l}\text { Mean Degree of } \\
\text { Mobility }\end{array}$ & \\
\hline $\begin{array}{l}\text { Mean OHI-S Index } \\
\text { Value }\end{array}$ & $1.18 \pm 0.47 \pm 0.53$ & $2.080 \pm 0.46$ \\
\hline $\begin{array}{l}\text { Mean } \pm \text { S.E.; P }<0.05 \\
\end{array}$
\end{tabular}

Suzuki et al (1985) reported that depressed neutrophil functions is not restored after periodontal therapy and suggested that such neutrophil dysfunction is congenital. Van Dyke et al (1985) reported the same result from family studies.

In this study, we report the clinical and hematological profiles of chronic periodontitis (JP and non- JP) patients in the SouthWestern zone of Nigeria. We have demonstrated that the hematological range of values (including the neutrophil and lymphocyte) for these patients falls within the accepted normal range of values in the Tropics Ezeillo (1981) Ukaejiofor (1979).

When these values were compared between the two different groups (JP and non $\mathrm{JP}$ ) it was also observed that there was no significant difference, suggesting that the quantitative values of haematological indices are not associated with chronic periodontal diseases.

Table 2: Mean haematological values of JP and Non JP patients

\begin{tabular}{|c|c|c|c|c|c|c|c|c|c|c|c|c|}
\hline \multirow[t]{2}{*}{ Subject } & \multirow[t]{2}{*}{ Age } & \multirow[t]{2}{*}{$\begin{array}{l}\text { Mean } \\
\text { PCV }\end{array}$} & \multirow{2}{*}{$\begin{array}{l}\text { Total } \\
\text { WBC } \\
X \\
10^{9} / \mathrm{L}\end{array}$} & \multicolumn{5}{|c|}{ Differential counts (\%) } & \multirow[t]{2}{*}{ Platelets } & \multicolumn{3}{|c|}{$\begin{array}{c}\text { Film } \\
\text { appearance }\end{array}$} \\
\hline & & & & $\mathrm{N}$ & $\bar{L}$ & $\bar{M}$ & $\mathrm{~B}$ & $\bar{E}$ & & $\bar{N}$ & $\bar{A}$ & $\bar{M}$ \\
\hline $\begin{array}{l}\text { JP } \\
\text { Patients }\end{array}$ & 18.3 & $\begin{array}{l}0.41 \\
\pm 0.04\end{array}$ & $\begin{array}{l}5.34 \\
\pm 1.65\end{array}$ & $\begin{array}{l}42.9 \\
\pm 6.29\end{array}$ & $\begin{array}{l}51.9 \pm \\
5.32\end{array}$ & $\begin{array}{l}0.65 \\
\pm 0.75\end{array}$ & 0 & $\begin{array}{l}4.5 \pm \\
1.5\end{array}$ & $\begin{array}{l}199.75 \\
\pm 14.46\end{array}$ & 16 & 2 & 2 \\
\hline $\begin{array}{l}\text { Non-JP } \\
\text { Patients }\end{array}$ & 19.3 & $\begin{array}{l}0.39 \\
\pm 0.01 \\
\end{array}$ & $\begin{array}{l}6.09 \\
\pm 1.48 \\
\end{array}$ & $\begin{array}{l}48.9 \\
\pm 4.8 \\
\end{array}$ & $\begin{array}{l}49.6 \\
\pm 4.56 \\
\end{array}$ & $\begin{array}{l}0.63 \\
\pm 0.76 \\
\end{array}$ & $\begin{array}{l}0.4 \\
\pm 0.6 \\
\end{array}$ & $\begin{array}{l}0.8 \pm \\
0.8\end{array}$ & $\begin{array}{l}183.06 \\
\pm 9.97 \\
\end{array}$ & 18 & 1 & 1 \\
\hline $\begin{array}{l}\text { Normal } \\
\text { Patients }\end{array}$ & & $\begin{array}{l}0.40 \\
\pm .05\end{array}$ & 4- 10 & 60 & 35 & 2 & 1 & 2 & 250 & - & - & - \\
\hline
\end{tabular}


Neutrophil being the principal cell type involved in host defenses against extrinsic bacteria attack, its function must be evaluated by assessing the entire process from chemotactic response to digestion of antigens. The relationship of periodontal disease to other neutrophil functions such as phagoytosis and bactericidal activity requires further investigation.

Further Studies need to be conducted comparing different races as well as investigating a large number of families with multiple members affected to help identifying the linkage of periodontal disease with specific human leukocyte antigen (HLA) phenotypes.

In conclusion, rather than the quantitative values of these cells (neutrophil and lymphocyte) which we found to be within the accepted normal range of values in the tropics, their defective functions (qualitative value) as reported previously may explain the pathogenesis of EOP of which JP is one.

ACKNOWLEDCEMENT: The authors acknowledge the immense contribution of Mr. S.A. Olomu of the Haematology research Laboratory, College of Medicine, University of Ibadan, Ibadan for the laboratory processing of the blood samples.

\section{REFERENCES}

Chihara, T, Arai H, Akutsu 1. (1993): Host defensive functions in a family manifesting early-onset periodontitis. J. Dent. Res. 72 (Spec. Issue): 405 (Abst. 2415).

Ezeillo GC (1981). White Blood Cell Counts in Healthy Africans. Nigerian Medical Practitioners; Vol. 12;73-78

Fenesy K.E. (1998): Periodontal disease: an overview for physicians. Mount Sinai Journal of Medicine. 65(56):362-9.

Genco RJ, (1992): Host responses in periodontal disease. Current concepts. J. Periodontol. 63:338-355.

Genco RJ, Can Duke TE, Levine MJ, Nelson RD, Wilson NM. (1986): Molecular factors influencing neutrophil defects in Periodontal disease. J. Dent. Res 65:137984.

Johnson NW, Griffiths GS, Wilton JMA. (1988): Detection of high-risk groups and individuals for periodontal diseases. Evidence for the existence of high-risk groups and individuals and approaches to their detection. J. Clin Periodontol. 15:27282.

Katz J, Goultschin J, Benoliel R, Schlesinger M. (1988): Peripheral T lymphocyte subsets in rapidly progressive periodontitis. J. Clin Periodontol. 15:266268.

Kinane DF, Johnson FA, Evans CW. (1989): Depressed helper-to-suppressor Tcell ratios in early-onset forms of periodontal disease. J. Periodont. Res. 24:161-164.

Mcfarlane CG, Meikle MC (1991): Interlenkin-2, interienkin-2 receptor and interlenkin-4 level are elevated in the sera of patients with periodontal disease. J. Periodont. Res. 26:402-408.

Mcfarlane (,G, Reynolds JJ, Meikle MC. (1990): The release of interferon by cultured peripheral blood monomuclear cells from patients with periodontitis. J. Periodontol. Res. 25:207-214.

Nishimura F, Atsushi $\mathbf{N}$, Kurimoto $\mathbf{K}$, Isoshima 0, Takashiba $\mathbf{S}$, Jobayahsi $\mathbf{M}$, Akutsu 1, Kurihara $\mathrm{H}$, Nomura $\mathrm{Y}$, Murayama Y, Ohta H, Kato K. (1990): A family study of Mother and Daughter with increased susceptibility. to Early-Onset Periodontitis, Microbiological, immunological, Host Def6nsive and Genetic Analysis. J. Periodontol.61:755-765.

Page RC, Altman LC, Ebersole JL. (1983a): Rapidly progressive periodontitis. A distinct clinical condition. J. Periodontol. 54:199-209.

Page RC, Bowen T, Altman LC (1983b): Prepubertal periodontitis. Definition of $a$ clinical disease entity. J. Periodontal. 54:261-271.

Page RC, Schroeder HE. (1982): Periodontitis in Man and Other Animals. A comparative. Review New York: Karger. 1982.

Page RC, Sims TJ, Geissler F, Altman LC, Baab DA. (1985): Defective neutrophil and monocyte motility in patients with early onset periodontitis. Infect immun. 47:169- 75

Schei O. Waerhang J, Lordal A, Arno a. (1959): Alveolar bone loss as related to oral hygiene and age. J. Periodontol. 30- 7-16.

Suzuki JB, Risom L, Falkner WA, Collwison C, Jr Bowers G. (1985): Effect of periodontal therapy on spontaneous lumphocyte response and neutrophil chemotaxis in localized and generalized juvenile periodontitis patients. J. Clin periodontal. 12: 124-131.

Ukaejlofor W.A., Isaacs- Sodeye, Seyide Adigun E and Ipadeola A (1979). Normal haematolo(,ical values in Adult Nigerians: Nigerian Medical Jorunal Vol. 9; No 1: 111 119

Van Dyke T'E, Schewinebraten M, Ganiciola LJ, Offenbacher S, Genco RJ. (1985): Neutrophil chemotaxis in families with localizes juvenile periodontitis. J. Periodont. Res. 20:503-514. 
African Journal of Biomedical Research Vol 5 (2002)/ Dosumu, Arowolo, Akande and Akingbola 